\title{
Food practices and their meanings in the daily routine of a university
}

\section{Práticas alimentares e seus significados no cotidiano de uma universidade}

\author{
Lilian Fernanda GALESI-PACHECO ${ }^{1}$ iD 0000-0002-6453-0356 \\ Carla Maria VIEIRA' ${ }^{1}$ iD 0000-0002-4486-4527 \\ Milena Cristina Sendão FERREIRA ${ }^{1}$ iD 0000-0002-5563-9384 \\ Maria Rita Marques de OLIVEIRA' ${ }^{1}$ (D) 0000-0003-1226-4364
}

\section{A B S T R A C T}

\section{Objective}

This study aimed at knowing and analyzing sociocultural meanings of the daily dietary practices revealed by a university community, in the context of a wellness program to their community and its surroundings.

\section{Methods}

The research team ran 28 workshops with the participation of 34 university units and 558 subjects in total. All workshops were recorded and transcribed verbatim. Content analysis was performed with the identification of emerging themes and categories.

\section{Results}

From the analysis of this material four categories emerged. There is the desire caused by the pleasure of having meals in a group of people and consuming foods rich in fat and sugar, but with its consumption shrouded by guilt. Healthy foods were considered important but related to obligation and displeasure. The community also wants to consume healthy foods daily in the academic environment, however, pointed out barriers such as an increasing pace of work and lack of time.

\footnotetext{
1 Universidade Estadual Paulista Júlio de Mesquita Filho, Instituto de Biociências, Departamento de Educação. R. Prof. Dr. Antonio Celso Wagner Zanin, s/n., Rubião Júnior, 18618-689, Botucatu, SP, Brasil. Correspondence to: LF GALESI-PACHECO. E-mail: <lilian.galesi@unesp.br>.

Support: This study was financed by Santander Bank, with its resources allocated to Unesp. Fundunesp provided the resources for this postdoctoral fellowship.

How to cite this article

Galesi-Pacheco LF, Vieira CM, Ferreira MCS, Oliveira MRM. Food practices and their meanings in the daily routine of a university. Rev Nutr. 2019;32:e180208. http://dx.doi.org/10.1590/1678-9865201932 el80208
} 


\section{Conclusion}

It was possible to identify barriers and desires related to food practices in the daily life of the university. This study demonstrated that changing the eating behavior of an academic community is a major challenge for wellness programs, even for an institution that produces and disseminates scientific knowledge.

Keywords: Eating behavior. Healthy diet. Universities. Wellness program.

\section{RESU M O}

\section{Objetivo}

Este trabalho teve como objetivo conhecer e analisar os significados socioculturais das práticas alimentares cotidianas revelados pela comunidade de uma universidade brasileira no contexto de um programa de bem estar para sua comunidade e entornos.

\section{Métodos}

Foram realizadas 28 oficinas com a participação de 34 unidades universitárias e 558 pessoas. Todas as oficinas tiveram seu áudio gravado e transcrito. Foi realizada análise de conteúdo com a identificação de temas e categorias emergentes.

\section{Resultados}

A partir da análise do material transcrito, emergiram os significados em quatro categorias. Há o desejo pelo prazer de realizar as refeições em grupo e consumir alimentos ricos em gordura e açúcar, mas envolto por culpa. Alimentos saudáveis foram considerados importantes, mas seu consumo foi relacionado à obrigação e desprazer. Contudo, a comunidade deseja consumi-los diariamente no ambiente acadêmico, mas aponta barreiras como o aumento do ritmo de trabalho e falta de tempo.

\section{Conclusão}

Foi possivvel identificar barreiras e desejos relacionados às práticas alimentares no cotidiano da universidade. Este estudo mostrou que transformar o comportamento alimentar de uma comunidade acadêmica é um grande desafio para os programas de bem-estar, mesmo para instituições que produzem e disseminam conhecimentos científicos.

Palavras-chave: Comportamento alimentar. Alimentação saudável. Universidades. Promoção da saúde.

\section{NTROD U CTION}

Considering the behavioral of life pattern, evidence suggests that prevention and control of behavioral risk factors are essential to prevent the epidemic growth of diseases and its serious consequences for the quality of life. Promoting health for individuals and communities aims to ensure access to health knowledge and make environments conducive to healthier choices $[1,2]$.

The social nature of eating is closely related to diet quality, state of health and lifestyle, performing an important role in the quality of human life [3]. However, quality of life is a subjective feeling of well-being, in which only the person can inform which behaviors lead him to his current conditions. In addition, there are food choices that can represent pleasure, satisfaction, and happiness, even though science classifies them as inadequate [4].

Eating practices which involve everyday aspects such as what one wishes to eat, his choices, the way of preparation and consumption and even the place where one has its meals, display sociocultural aspects as the cultural identity, the social condition and family memory, which turns food and nutritional education to promote more health-friendly choices into complex processes [5].

In this context, the University represents an important locus of knowledge production, space of criticism and formation of opinion in favor of improving the quality of life of people $[6,7]$. Based 
on this premise, this study aimed at knowing and analyzing the sociocultural meanings of daily food practices revealed by a university community, in the context of a project whose objective was to promote well-being to its community and surroundings.

\section{METHOD S}

The present study is a segment of the activities of an institutional project of Unesp entitled Rede Viva Melhor (RVM, Live Better Network). Universidade Estadual Paulista "Júlio de Mesquista Filho" (Unesp, São Paulo State University "Júlio de Mesquita Filho") is a Brazilian public university that has 34 units distributed in 24 cities in the State of São Paulo.

In 2014, RVM started its activities at Unesp. The objective was to involve the university units in a network focused on the promotion of healthy living behaviors, environmentally sustainable habits, integrating both internal and surrounding communities. The project had a structure of 34 articulators (professors or staff), one in each unit of Unesp, and a coordinating team. The articulators were responsible for encouraging, promoting and supporting local collective activities to promote well-being and caring for the environment.

\section{Data collection}

This is a qualitative nature study inserted in the proposal of collaborative action research [8]. With the objective of presenting RVM to the university community, starting activities and forming groups interested in promoting health and well-being in the campus, workshops were held in all units of Unesp, adopting the definition of workshop proposed by Afonso \& Coutinho [9].

The university community (students, professors and staff) was invited to participate in the workshops, without any exclusion criteria. The invitation was made locally by the articulator, through posters made available on the premises of the units and visits to the different sectors, classrooms and departments.

The research team ran 28 workshops at the university. Another two workshops have been conducted as a pilot study. An average of 20 participants attended each workshop, most of whom were part of the university staff (67.0\%), followed by students (23.8\%) and professors $(9.2 \%)$, totaling 558 people. The average age of participants was $39( \pm 15.1)$, with a higher female representation (66.5\%).

The workshops were led by a professional with experience in coordinating group educational activities in the format of workshops. The workshops lasted for 1 hour to 2 hours. The signature of the consent form by each attendant, as well as clarifications regarding the recording of the audio and its utilization followed the activities. All the workshops had their audio recorded and transcribed verbatim. Field notes were made during the workshops. The sociocultural meanings of the theme "food practices" revealed in the workshops were the focus of this study.

The research considered the ethical precepts of confidentiality, secrecy and anonymity and its activities received a favorable opinion from the Committee of Ethics of Research in Human Beings of the Unesp College of Medicine (Botucatu, Brazil), available as document No.306.623. 


\section{Data analysis}

The analysis was performed from reading the transcribed material and searching for the flow of its interpretations and meanings attributed to food practices. In order to develop it, a content analysis was carried out according to Bardin [10]. The pre-analysis then performed and provided intense readings and re-readings of the material. The initial categorization of the material was then performed.

In order to validate it, the analysis was done independently by two researchers, who identified emerging themes and categories. The researchers then had a meeting in order to establish the best categorization and sub categorization methodology until all categories were sorted and segregated.

The categories were named after the characteristics of the content that emerged from the analyzes. From the interpretation of the data and to support the analysis and discussion of the results, around the central theme of food practices, the referential for the analysis utilized was anthropology in the sociocultural current, scientific field of Food and Culture [11]. The Atlas.ti ${ }^{\circledR}$ (Berlin, Germany) version 8.0, software was used as an aid to organize the collected data.

\section{RE S U L T S}

The analysis of the transcribed material allowed the emergence of meanings of food practices in the context of health promotion and well-being by the university community, which were organized in four different categories: it is tasty and healthy, it is tasty but not healthy, it is healthy but not tasty and is neither tasty nor healthy. Quotes from the participants from these workshops were arranged to better illustrate the content of emerging categories and subcategories.

\section{It is tasty and healthy}

The community of the university valued moments of fraternization and food sharing in the work environment promoting integration, bonding and conviviality.

We had an experience of proposing a conjoint breakfast with our colleagues from one of the university sections. Each person brought something and it gave us that possibility of getting together in a much better way than if it was just the regular working relationship.

The food itself, as well as having a meal together and the exchange of recipes were considered as conducting means of harmonious conditions of coexistence and affection.

We call those interested in exchanging recipes and have a get-together. I bring bread, for example, that I do for everyone to try. So, every day one of us brings food and their ideas, and then people will learn how to eat.

\section{It is tasty but not healthy}

Foods with high levels of fat and sugar were considered as handy and as promoters of pleasure, as well as being desired in meetings and birthday parties inside the university.

At department meetings, there is soda and snacks. We ask the purchasing department: 'Look, can't we have a fruit salad, some juice?' But people don't want to! If you give people the option of 
having baked snacks, nobody wants them, everyone wants fried snacks... [laughter]. Baked snacks aren't tasty.

However, the consumption of these types of foods has been related to emotional eating guilt, to "knowing that it is bad for health" and to the feeling that one should not eat it.

Sometimes l'm in the cafeteria, washing my fruit, and someone walks in to eat something that is not so healthy and then they say, 'I'm not even going to offer you, you're eating fruit and l'm eating something here that I wasn't supposed to be eating'.

We gotta enjoy it because when we talk about birthday parties and such, we soon think about cakes, sodas, in different snacks and drinks that each one is going to bring. And then we have fried foods and a lot of things that are not healthy for us, and it affects our emotional side, the integration, but the health aspect will not be so cool anymore.

\section{It is healthy but not tasty}

The consumption of fruit and vegetables was mentioned by the participants as fundamental for being healthy and for one's well-being. However, eating them was seen as obligation and something without pleasure.

What is best for me? Eating fruit, eating vegetables. I know I need to assimilate these healthy eating habits indeed, but I am bad at it. It's not enough just knowing that it's good to eat fruit and then filling my stomach with cake and snacks.

We discussed about how people behave towards food, and most people say they prefer to eat what they like and not what they should. I cannot eat something I do not like to eat.

The community also revealed the feeling of powerlessness due to the lack of skills needed to prepare healthy foods, and it is still a habit that is far from their everyday lives, but they are aware that it needs to be improved.

I know what's good for me, but I can't! I can not stop and make a proper lunch because I do not like it. I will do this, eat what I have, eat only bread.

\section{It is neither tasty nor healthy}

In contrast to the "tasty but unhealthy" category, whilst craving and often consuming foods rich in fat and sugar, the community reports that they do not enjoy consuming them as their only option, as a part of daily meals, such as lunch and dinner. A lot of criticism was made regarding the food available in the cafeterias and restaurants inside the university units, mainly related to the lack of options considered healthier such as natural sandwiches, baked snacks, juices and a greater variety of vegetables.

The cafeterias do not have natural sandwiches available. They only have snacks. We have no choice.

So, sometimes the students work outside the campus, and when they get there, they eat something and they have to eat a snack and a soda. I've been eating this myself for four years.

Lack of time to cook and eat properly, inadequate working conditions were other factors, considered subcategories of "neither tasty nor healthy", which meant more barriers to achieving healthy eating habits, contributors to the well-being. 
I think this everyday rush does not allow you to stop to think about what you want in your day to day life, or what you need for a healthy diet. You eat what's faster, what's more time-saving, not what you would like to eat.

\section{DISCUSSION}

In the discussions, food was brought up as a means of bringing people together, and eating together is responsible for promoting pleasant moments among people in the work environment.

Nascimento [12] presents ways to represent the action of sitting together to eat and shows group meals as an opportunity to socialize, to develop alliances and to foster understanding among the people. The pleasure of eating stimulates and unfolds itself in the pleasure of interacting, insofar as it is an instrument of communication and aggregation.

In the study of Park et al. [13] developed in South Korea, having meals with co-workers was also valued. Lunch was seen by most of the participants as a group activity, which allows the integration of workers, emphasizing the social role of food. When they stay alone in the office, workers tend to skip lunch because they find it uncomfortable to eat alone.

In Brazil, we are experiencing a process of disrupting food practices, characterized by the deregulation and simplification of meals, with a reduction of time dedicated to them and a change to the traditional times of meals. Meals are served at work, inside offices through fast and convenient meals. Thus, socialized eating, which used to be an everyday and repetitive practice, is now reserved as a way of leisure [14]. When eating together happens on a daily basis and provides an opportunity to integrate with co-workers, especially when one can offer something to the other such as the food itself or a recipe, the moment is valued and perceived as enjoyable.

At times of meeting and fraternization among colleagues, the workshop's participating groups revealed the pleasure in eating foods rich in sugar and fat. However, why do we consume these foods, even if they are delicious, as we point them as unhealthy?

The human preference for foods with high levels of fat and sugar can be influenced by many factors, such as biological, economical and sociocultural factors. In 1963, Luís da Câmara Cascudo [15] reported in his book "The History of Food in Brazil" that people maintain their traditional eating habits because for the people there is no convincing, technical and compelling argument against the taste itself.

Fat contributes to the texture, flavor and aroma of a wide variety of foods, being responsible for greater palatability, acceptance of taste and satisfaction in its consumption, in addition to promoting the feeling of satiety. Parallel to the preference for fat is the preference for sugar, present since birth which may be due to genetic predisposition, to behavioral, emotional, economic and socio-cultural factors [16].

Also involving sensorial aspects, it is important to mention the orientation of the choices for tasty and energetic foods in stress situations experienced by the study participants, as reported by them in the workshop discussions. Especially among women, this preference is regarded to be caused hormones such as cortisol, leptin, insulin and neuropeptide $Y$ that stimulate the desire for these foods, which are consumed as a way to ease off an altered emotional state $[17,18]$.

In spite of the desire for eating foods rich in fat and sugar, its consumption was reported by the university community as something for which they felt "guilt" and that they "needed to justify it". 
The same type of testimony was found in the study carried out by interviewing 710 UK consumers, in which the consumption of unhealthy foods was associated with feelings of guilt and shame [19].

According to Polivy, [20] people compare what others are eating to what they themselves eat, and draw conclusions about these comparisons about how much and which types of food to consume. This action stems from our inner need to evaluate our opinions, abilities and emotions by looking at how others act.

Scientific evidence has demonstrated and sustained the consumption of fruits and vegetables as an important strategy to control and reduce chronic non-communicable diseases, but success in increasing their consumption has been very limited. Cost, access, availability, convenience, family and friends preferences, cultural influences, diseases, taste beyond the pressure of the media and the food and beverage industry to redirect choices are some of the factors responsible for this scenario [21-23]. As quoted by Machado et al. [24], these aspects shape eating behavior more than the actual knowledge of health benefits.

Multiple information on diet, food, and cooking are always present in our lives. Such narratives, which sometimes converge, sometimes conflict, impose on society a constant state of alertness and vigilance on the novelties that may arise [14]. The question regarding what should actually be consumed in association with the old prescriptive practices on food and nutrition causes us to remain stagnant in our habits and accommodated with practices linked to our culture and related to the convenience and taste of food. At the same time, there was a feeling of powerlessness to improve eating behavior in daily work, both individually and collectively.

The authors' attention is drawn to the fact that the uncertainties about adequate food and the difficulty of improving it are present in the university community, so close to the production and dissemination of scientific knowledge.

The concern to improve eating behaviors within the university was also pointed out in a review of the literature [25]. Based on 37 studies, the authors pointed out the need for public policies to promote healthy eating in the face of an unfavorable scenario regarding the eating habits of students.

By revaluing time and pressures exerted by factors such as an increased workload, higher productivity requirements and shorter meal times, the population has meals outside their homes. Besides that, the meal breaks have now been shared with other activities such as working, studying, watching television, interacting with the mobile device, often alone and standing, next to a counter. Coupled with this new eating profile, the food and the advertising industry reinforce the idea of developing home-prepared meals with minimal effort, or meals easily prepared away from home as a timesaving practice $[13,26,27]$ Perhaps these are some of the reasons why we seek satisfaction in the pleasure provided by the sensory components of food and the sense of fullness given by the amount of food eaten.

This study was developed from the context of wellness program for a university community and we chose to evaluate the discussions generated during workshops. It was a different way of doing it as we worked on the different ideas that the discussions generated. We considered as a limitation that we were not able to capture the ideas of all the attendants to compose this analysis, as it was only possible to record people who spoke out. Moreover, since the group was large and open to interventions, it was not possible to identify each of the attendants' speeches. In addition, people who attended the workshops were the ones who felt touched by the proposal and we have no guarantee that the invitation actually reached all students, university staff and professors, given the great physical extension of the university studied. 


\section{CONCLUSION}

It was possible to identify barriers and desires related to food practices in the daily life of the university. On the one hand, the community wants to have the pleasure of eating together and consuming foods with high levels of fat and sugar, but then people feel guilty about eating them. Healthy foods are considered important, but their consumption was related to obligation and displeasure. On the other hand, there is the desire to consume healthy foods daily, but there are barriers such as the increasing amount of work and lack of time.

Faced with the daily life of the university, one must understand the importance to comprehend the complexity generated by the socio-cultural issues involved in food practices. In this sense, this study demonstrated that changing the eating behavior of an academic community is a major challenge for wellness programs, even for an institution that produces and disseminates scientific knowledge.

\section{CONTRIBUTORS}

LF GALESI-PACHECO was involved in the study design, analysis and writing of the article; CM VIEIRA participated in the study design and critical review; MCS FERREIRA was involved in study design and data collect; MRM OLIVEIRA participated in analysis, interpretation and collected the data. All authors reviewed the manuscript.

\section{ACKNOWLEDGMENTS}

The authors would like to thanks the articulators who supported the organization of the workshops.

\section{REFERENCES}

1. Iser BPM, Claro RM, Moura EC, Malta DC, Morais Neto OL. Fatores de risco e proteção para doenças crônicas não transmissíveis obtidos por inquérito telefônico: Vigitel Brasil 2009. Rev Bras Epidemiol. 2011;14(1):90-102. http://dx.doi.org/10.1590/S1415-790X2011000500010

2. Ribeiro $A G$, Cotta RMM, Ribeiro SMR. A promoção da saúde e a prevenção integrada dos fatores de risco para doenças cardiovasculares. Ciênc Saúde Coletiva. 2012;17(1):7-17. http://dx.doi.org/10.1590/S1413-81 232012000100002

3. Holm L, Lund TB, Niva M. Eating practices and diet quality: A population study of four Nordic countries. Eur J Clin Nutr. 2015;69(7):791-8. http://dx.doi.org/10.1038/ejcn.2015.61

4. Santos LAS. O corpo, o comer e a comida: um estudo sobre as práticas corporais alimentares cotidianas a partir da cidade de Salvador - Bahia. Salvador: EDUFBA; 2008. http://dx.doi.org/10.7476/9788523211707

5. Garcia RWD. A antropologia aplicada às diferentes àreas da nutrição. In: Canesqui AM, Garcia RWD, editores. Antropologia e nutrição: um diálogo possível. Rio de Janeiro: Fiocruz; 2005. p.275-86. http://dx. doi.org/10.7476/9788575413876

6. Trevizan SP. Ciência, meio ambiente e qualidade de vida: uma proposta de pesquisa para uma universidade comprometida com sua comunidade. Ciênc Saúde Coletiva. 2000;5(1):179-86. http://dx.doi.org/10.1590/ S1413-81232000000100015

7. Taylor A. Perspectives on the University as a business: The corporate management structure, neoliberalism and higher education. J Crit Educ Pol Stud. 2017 [cited 2017 Jun 27];15:108-35. Available from: http:// www.jceps.com/wp-content/uploads/2017/03/15-1-6.pdf.

8. Franco MAS. Pedagogia da pesquisa-ação. Educ Pesq. 2005;31(3):483-502. http://dx.doi.org/10.1590/ S1517-97022005000300011 
9. Afonso MLM, Coutinho ARA. Metodologias de trabalho com grupos e sua utilização na área da saúde. In: Afonso MLM, editor. Oficinas em dinâmica de grupo na área da saúde Itatiba: Casa do Psicólogo; 2006. p.59-83.

10. Bardin L. Análise de conteúdo. 70a ed. Lisboa: LDA; 2009.

11. Silva JK, Prado SD, Carvalho CVS, Ornelas TFS, Oliveira PF. Alimentação e cultura como campo científico no Brasil. Rev Saúde Coletiva. 2010;20(2):413-42. http://dx.doi.org/10.1590/S0103-73312010000200005

12. Nascimento AB. Comida: prazeres, gozos e transgressões. 2a ed. Salvador: EDUFBA; 2007. http://dx.doi. org/10.7476/9788523209070

13. Park S, Sung E, Choi Y, Ryu S, Chang Y, Gittelsohn J. Sociocultural factors influencing eating practices among office workers in urban South Korea. J Nutr Educ Behav. 2017;49(6):466-74. http://dx.doi.org/10.1016/j. jneb.2017.02.005

14. Santos SMC. Alimentação e nutrição um diálogo com os princípios de qualidade de vida. In: Freitas MCS, Fontes GAV, Oliveira N, editores. Escritas e narrativas sobre alimentação e cultura. Salvador: EDUFBA; 2008. p.261-75.

15. Cascudo LC. História da alimentação no Brasil. 4a ed. São Paulo: Global Editora; 2017.

16. Drewnowski A, Almiron-Roig E. Human perceptions and preferences for fat-rich foods. In: Montmayeur JP, Le J, editors. Fat detection: Taste, texture, and post ingestive effects. Boca Raton: Taylor \& Francis; 2010.

17. Zellner DA, Saito S, Gonzalez J. The effect of stress on men's food selection. Appetite. 2007;49(3):696-9. http://dx.doi.org/10.1016/j.appet.2007.06.013

18. Adam TC, Epel ES. Stress, eating and the reward system. Physiol Behav. 2007;91(4):449-58. http://dx.doi. org/10.1016/j.physbeh.2007.04.011

19. Piqueras-Fiszman B, Jaeger SR. The incidental influence of memories of past eating occasions on consumers' emotional responses to food and food-related behaviors. Front Psychol. 2016;7(943):1-13. http://dx.doi. org/10.3389/fpsyg.2016.00943

20. Polivy J. What's that you're eating? Social comparison and eating behavior. J Eat Disord. 2017;5(18):1-5. http://dx.doi.org/10.1186/s40337-017-0148-0

21. Gomes FS. Frutas, legumes e verduras: recomendações técnicas versus constructos sociais. Rev Nutr. 2007;20(6):669-80. http://dx.doi.org/10.1590/\$1415-52732007000600009

22. Morgan EH, Vatucawaqa P, Snowdon W, Worsley A, Dangour AD, Locket K. Factors influencing fruit and vegetable intake among urban Fijians: A qualitative study. Appetite. 2016;101:114-8. http://dx.doi. org/10.1016/j.appet.2016.03.003

23. Vollmer RL, Baietto J. Practices and preferences: Exploring the relationships between food-related parenting practices and child food preferences for high fat and/or sugar foods, fruits, and vegetables. Appetite. 2017;113:134-40. http://dx.doi.org/10.1016/j.appet.2017.02.019

24. Machado IK, Becker D, Campos DM, Wendt GW, Lisboa CSM. Repercussões do cenário contemporâneo no ato de compartilhar refeições em família. Psicol Argum. 2014;32(76):117-27. http://dx.doi.org/10.7213/ psicol.argum.32.076.A007

25. Bernardo GL, Jomori MM, Fernandes AC, Proença RPC. Food intake of university students. Rev Nutr. 2017;30(6):847-65. http://dx.doi.org/10.1590/1678-98652017000600016

26. Arnaiz MG. Em direção a uma nova ordem alimentar? In: Canesqui AM, Garcia RWD, editores. Antropologia e Nutrição: um diálogo possível. Rio de Janeiro: Fiocruz; 2005. p.147-64. http://dx.doi.org/10.74 76/9788575413876

27. Oliveira N, Freitas MCS. Fast-food: um aspecto da modernidade alimentar. In: Freitas MCS, Fontes GAV, Oliveira N, editores. Escritas e narrativas sobre alimentação e cultura. Salvador: EDUFBA; 2008. p.239-60. 